sciendo Порівняльна професійна педагогіка 8(2)/2018 Comparative Professional Pedagogy 8(2)/2018

DOI: $10.2478 / \mathrm{rpp}-2018-0015$

Doctor of Science in Pepagogy, Full Professor, HANNA TOVKANETS Mukachevo State University, Ukraine Address: 26 Uzhhorodska St., Mukachevo, 89600, Ukraine E-mail: tovkanec@rambler.ru

\title{
LIFELONG LEARNING IN ENHANCING PROFESSIONAL TEACHER TRAINING IN THE EUROPEAN COUNTRIES
}

Research relevance is determined by the need to enhance teacher education, consolidate teachers' further professional and personal development, increase the prestige of the teaching profession. The article focuses on enhancing professional training of teachers in the European countries under the conditions of lifelong learning. Based on the study and analysis of reseaches by Ukrainian and foreign scholars and some statistical information, the peculiarities of teaching and teacher training have been justified. Mentoring has been described as a way of transferring experience, knowledge, abilities and skills from one age group to another, or from one person to another. It has been found that mentoring aims to provide support and promote self-realization in professional activity. Lifelong learning has been defined as a programme for thinking and activity development. The statistical data on the needs of teacher development and thematic demand and supply in lifelong learning have been analyzed. It has been emphasized that modern trends in the development of lifelong learning for teachers in the EU countries include consolidation and rationalization of organizational structures with the purpose of developing the national systems of postgraduate teacher education based on scientific principles of organization and management theory, as well as orientation towards reaching the balance between the interests of all participants, partners, central authorities of education management, regional and local education authorities, school administration, teachers; stimulating innovative activities of teachers, etc. It has been concluded that taking into account European experience in organizing lifelong learning for teachers will allow Ukraine to enhance professional training of teachers, professionalization in self-education, their reflexive practice of searching for effective ways to integrate the latest technologies into the education process.

Keywords: professional training, teacher, lifelong learning, European educational space.

\section{INTRODUCTION}

The development of a single open educational space allows enhancing the scope of the national education system. It must be noted that teachers play a decisive role in education development in the European countries in the early 21st century. It has become one of the priorities in the European educational policy (Indikatory sostoianiya, 2017; Tovkanets, 2017; Evropská komise/EACEA/Eurydice, 2015), in which the key position is determined by the need to enhance teacher education, consolidate their further professional development and increase the attractiveness of the teaching profession.

THE AIM OF THE STUDY

The article aims to justify the peculiarities of enhancing professional teacher training under the conditions of lifelong learning in the European countries. 
S sciendo Порівняльна професійна педагогіка 8(2)/2018

Comparative Professional Pedagogy 8(2)/2018

\section{THEORETICAL FRAMEWORK AND RESEARCH METHODS}

The need for quality teacher training requires addressing the problem of enhancing professional training and studying foreign experience, in particular in the system of lifelong learning. Problems of lifelong learning for teachers, their advanced and professional training in the international educational space and in Ukraine have been studied by both Ukrainian and foreign scholars (V. Andrushchenko, N. Avshenyuk, N. Bidyuk, L. DarlingHammond, V. Kremen, N. Nychkalo, O. Ohiienko, A. Parabuchev, J. Průcha, T. Sorochan, H. Tovkanets, L. Zormanová et al.

While researching, such methods as analysis, synthesis, comparison and generalization have been used in order to identify the peculiarities of teaching and teacher training in the European countries and to study relevant researches by Ukrainian and foreign scholars and statistical information.

\section{RESULTS}

Professional teacher training in the European countries is traditionally based on four- or five-year curricula. The peculiarities of teacher training presuppose high requirements at the admission level, since some European countries use special methods of selecting applicants, such as skills tests, personality tests or motivational interviews (Gehrke, 1988).

However, the beginning of professional teaching is associated with the need to provide teaching support in the form of mentoring, organize programmes for novice teachers, which help to become accustomed to the profession and prevent teaching staff attrition. Based on the data of many international organizations, such countries as Germany, Estonia, Ireland, France, Italy, Cyprus, Luxembourg, Malta, Austria, Portugal, Romania, Slovenia run special programmes aimed at facilitating novice teachers' adaptation to teaching (Evropská komise/EACEA/Eurydice, 2015).

Mentoring is viewed as a common additional form for enhancing initial teacher training. Although not all countries comprehensively and systematically implement mentoring, it is a rather popular practice in Europe. Mentoring is interpreted as a dynamic and interactive process in which one person, who usually holds a higher-level position and has significant professional achievements (a mentor), manages the process of developing a novice (an apprentice), whose effectiveness depends on the ability of both parties to build a constructive dialogue (Alleman, Cochran, Doverspike, \& Newman, 1984, p. 330; Gehrke, 1988, p. 191). Mentoring, on the one hand, is aimed at individual development of teachers training and support of novices during their professional development in the organization and among colleagues; development of their professional identity, transfer of mentors' knowledge and practical experience, career growth, advanced training; theory and practice combined; on the other hand, it is integral development, namely, information exchange, realization of specific plans and goals, development of leadership skills; prevention and elimination of staff turnover; development of corporate culture (a system of values, norms and rules of conduct, which regulate the interaction between individuals in this organization), staff training adapted to real needs of an educational organization, enterprise or institution. Mentoring primarily aims to consolidate knowledge, develop skills and abilities of a novice teacher, support them and promote their self-realization in professional activities (Mentoring Handbook, 2012). L. Darling-Hammond (2010) considers mentoring as a form of professional socialization, within which a more experienced (usually senior) employee performs the role of leader, consultant, teacher and patron of a less experienced employee (p. 18). 
The European strategy for enhancing education quality is based on lifelong learning for teachers. The European countries have achieved a unified understanding of lifelong learning significance, the need to design a specific plan of action and defined its key principles (Commission of the European Communities, 2000): new basic knowledge and skills for everyone; greater investment in human resources; innovative teaching and learning methodologies; a new system for monitoring acquired education; mentoring and counselling development; sustainable development of education.

The conducted analysis of scientific literature and documentary sources shows that teacher professional development under the conditions of lifelong learning in the EU countries is an important sociopolitical goal (Indikatory sostoianiya, 2017; Commission of the European Communities, 2000; Evropská komise/EACEA/Eurydice). In Europe, lifelong learning sustains professional development of teachers based on the elimination of age, social and organizational limits. Therefore, its goals include improving teachers' professional teaching skills, as well as developing their initiative and critical thinking.

The analysis of teachers' needs in the European countries proves that they primarily possess relevant teaching knowledge and skills. However, teachers need advanced training in those fields, which allow them to be more effective and modern, for example, in the field of information and education technologies. More than $50 \%$ of teachers are willing to further study such areas "Teaching Students with Special Educational Needs", "Applying Information Technologies in Education", "Innovative Technologies in education", etc. (Evropská komise/EACEA/Eurydice, 2015). However, in most EU countries, there is some contradiction between the supply of lifelong learning institutions and the demands for teacher professional development (Figure 1).

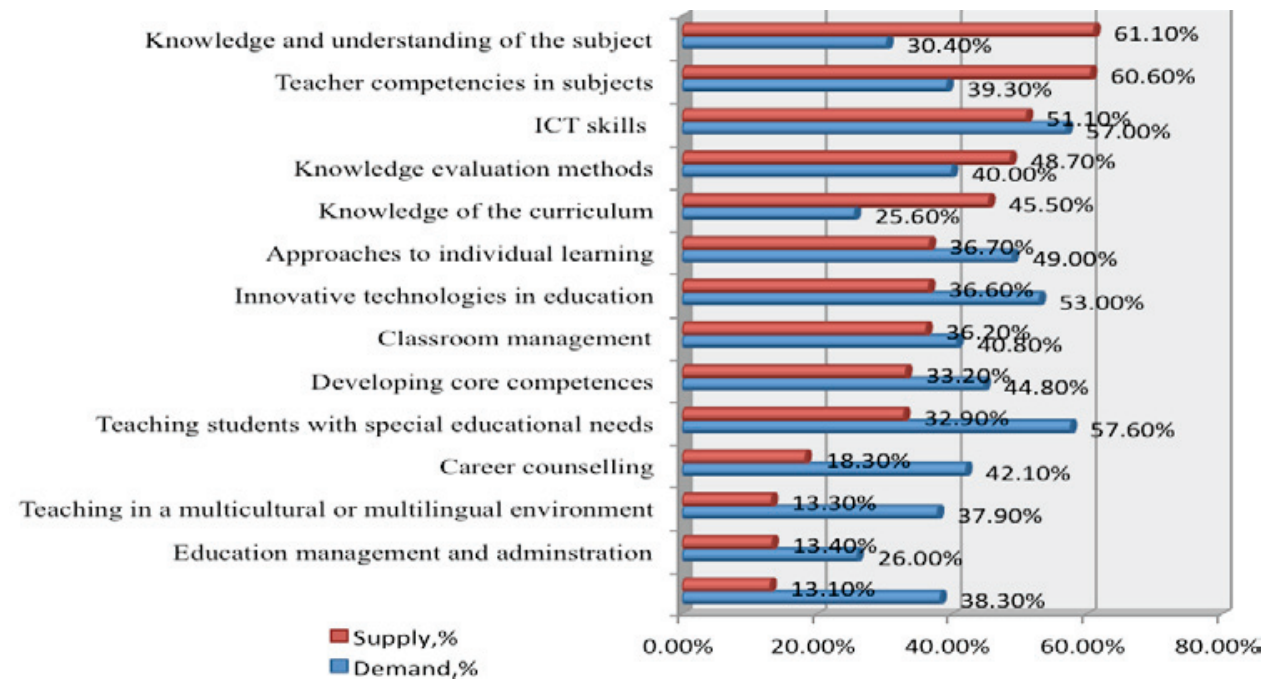

Fig. 1. Supply and demand based on the topics of lifelong learning curricula in the EU countries (Eurydice, 2013) 
sciendo Порівняльна професійна педагогіка 8(2)/2018

Comparative Professional Pedagogy 8(2)/2018

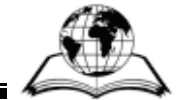

Thus, $38 \%$ of teachers would like to undergo professional training in such a topic as "Teaching in a Multicultural and Multilingual Environment", whereas only 13\% of courses, trainings, thematic conferences or seminars are devoted to it. Such a contradiction is also observed in "Career Counselling" (42.1\% and 18.3\%), "Teaching Students with Special Educational Needs" (57.6 \% and $32.9 \%$ ), "Developing Core Competences" (44.8 and 36.6), "Methods for Developing Interdisciplinary Competencies" (38.3 \% and 13, 01\%), "Education Management and Administration" (26.0\% and $13.4 \%$ ), etc. However, those topics, which are not in demand among teachers, are rather promoted. They are the following: "Knowledge and Understanding of the Subject" (30.4\% and 61.1\%), "Knowledge Evaluation Methods" (40.0\% and 48.7\%), "Teacher Competencies in Subjects" (39.3\% and 60.6 \%). As evidenced by the Figure 1, supply and demand for "ICT Skills" (57.0 and 51.1\%) coincide (Eurydice, 2013).

The analysis of scientific sources proves the need to improve supply in the field of lifelong learning. Teacher professional development contributes to international mobility. Modern European education policy provides opportunities for studying abroad.

According to some statistics, $27 \%$ of the EU teachers have undergone advanced teacher training abroad: mostly in Scandinavian countries - Iceland (70 \%), Norway - $54 \%$, Finland $-41 \%$, Sweden $-40 \%$, Denmark $-38 \%$, whereas in the Czech Republic $-31 \%$, Slovakia $-25 \%$, Poland - $22 \%$, Portugal - $19 \%$, Hungary - $16 \%$ (Eurydice, 2013). It must be noted that most respondents are foreign languages and social sciences teachers. Natural sciences teachers are less engaged in such activities.

Lifelong learning should be interpreted as a form of development management. Therefore, it is necessary to implement new approaches to enhancing education quality. The main idea of lifelong learning consists in developing the way of thinking and activities within which the process of developing individuals and production systems can only serve as a partial and fragmentary task. This is a special policy not only in the system of learning, but also in the organization of leisure, social relations and sociocultural systems.

The studies on lifelong learning for teachers prove relevance of this problem and a variety of approaches to its solving in different European countries. Thus, more than $65 \%$ of teachers prefer courses and trainings. In addition, it is very common to conduct individual or joint researches $-34,8 \%$. Conferences and seminars are also in demand among $32.4 \%$ of respondents (see Fig. 2).

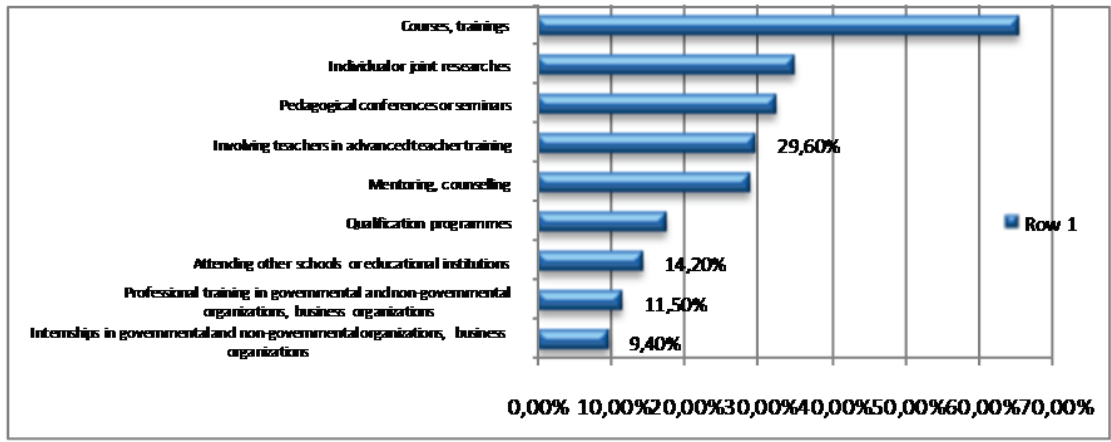

Fig. 2. Forms of lifelong learning organization for teachers in the EU (Evropská komise/EACEA/Eurydice, 2015, p. 69) 
Modern trends in development of lifelong learning for teachers in the European countries are consolidation and rationalization of organizational structures with the purpose of developing the national systems of postgraduate teacher education based on scientific principles of organization and management theory, as well as orientation towards reaching the balance between the interests of all participants, partners, central authorities of education management, regional and local education authorities, school administration, teachers; stimulating innovative activities of teachers, etc.

\section{CONCLUSIONS}

So, taking into account European experience in organizing lifelong learning for teachers will allow Ukraine to enhance professional teacher training, professionalization in self-study, reflexive practice of searching for effective ways to integrate the latest technologies into the education process.

Perspectives for further studies are seen in comparative analysis of teacher education development in the context of European integration.

\section{REFERENCES}

1. Alleman, E., Cochran, J., Doverspike, J., \& Newman, I. (1984). Enriching mentoring relationships. The Personnel and Guidance Journal, 62 (6), 329-332.

2. Commission of the European Comunities. (2000). A Memorandum on Lifelong Learning. Retrieved from http://arhiv.acs.si/dokumenti/Memorandum_on_Lifelong_ Learning.pdf.

3. Darling-Hammond, L. (2010). Recruiting and retaining teachers: turning around the race to the bottom in high-need schools. Journal of Curriculum and Instruction, 4 (1), $16-32$.

4. Evropská komise/EACEA/Eurydice. (2015). Profese učitele v Evropě: praxe, názory a př́stupy. Zpráva Eurydice. Lucemburk: Úřad pro publikace Evropské unie. P. 138.

5. Eurydice. (2013). Na základě údajů OECD, TALIS 2013. Zdroj http://eacea.ec.europa. eu/education/eurydice 27 (3), 190-194.

6. Gehrke, N. G. (1988). Toward a definition of mentoring. Theory into Practice,

7. Indikatory sostoianiya sistemy obrazovaniya v 2017 godu. (2017). Vzyato s https://www.kursobr.ru/images/112121.jpg.

8. Mentoring Handbook. (2012). Retrieved from http://aslect.eu /documents/ case1_Doing2learn/Doing2learn_Mentoring_.

9. Mrhač, J. (2005). Teorie a praxe školského managementu - ř́zení výchovy a vzdělávání. Ostrava: Centrum celoživotního vzdělávání PdF OU.

10. Parabuchev, A. I. (2005). Uchitel v epokhu obshchestvennykh transformatsyi. Voprosy obrazovaniya, 4, 246-260.

11. Průcha, J. (2002). Učitel. Současné poznatky o profesi. Praha: Portál.

12. Tovkanets, H. V. (2017). Formuvannia pedahohichnoi kultury maibutnoho pedahoha $v$ umovakh modernizatsii: metodolohichnyi ta metodychnyi aspekty. Mukachevo: MDU.

13. Zormanová, L. (2018). Učitelé v evropských zemích a jejich charakteristiky. Zdroj https://clanky.rvp.cz/clanek/c/Z/21636//. 